\title{
Biotransformation of tuna waste by co-fermentation into an aquafeed ingredient
}

\author{
Hena Vijayan ${ }^{1}$, Imelda Joseph ${ }^{2} \&$ Rajaian Paul Raj ${ }^{2}$ \\ ${ }^{1}$ Central Marine Fisheries Research Institute, Kochi-18, Kerala, India \\ ${ }^{2}$ Coastal Aquaculture Authority, Ministry of Agriculture, Government of India, Chennai-600 006,Tamil Nadu, India
}

Correspondence: Joseph, Senior Scientist, Central Marine Fisheries Research Institute (CMFRI), Cochin- 682 018, Kerala, India. E-mail: imeldajoseph@rediffmail.com

\begin{abstract}
Dried skipjack tuna (Katsuwonus pelamis) waste (red meat, gills, viscera, fins, etc.) were mixed with $25 \%$ wheat flour and inoculated with a starter culture of Lactobacillus plantarum National Collection of Industrial Microorganisms (NCIM) $2912 \quad\left(10^{8}-\right.$ $10^{9}$ cells $\mathrm{mL}^{-1}$ ) and Bacillus licheniformis MTCC $6824\left(10^{7}-10^{8}\right.$ cells $\left.\mathrm{mL}^{-1}\right)$. Changes in the nutritional quality (crude protein, crude fat, crude ash, crude fibre and nitrogen-free extract and aminoacids) were monitored during a fermentation period of 14 days. The proximate analysis showed significant changes in the composition of L. plantarum-fermented tuna (LPFT) and B. licheniformis-fermented tuna (BLFT) from the unfermented raw materials. Fermentation of tuna waste has resulted in a significant $(P<0.05)$ increase in the protein content of tuna waste between days 6 and 12 . All the amino acid contents in BLFT increased during fermentation, whereas, in LPFT the levels of serine, histidine, tyrosine, methionine, cystine and phenylalanine contents were decreased. A marginal increase in calcium and phosphorus levels was recorded in the fermented products. The results of the study suggest that LPFT or BLFT can be used as a novel aquafeed ingredient for different fish species.
\end{abstract}

Keywords: biotransformation, tuna waste, co-fermentation, aquafeed

\section{Introduction}

Large quantities of fish waste are generated from seafood processing in the canning industry and from cleaning the fish at the market. These wastes are either transformed into fish meal using costly proce- dures, dumped back into the ocean or disposed with the associated pollution problems. The tuna canning industry produces a large quantity of byproducts, forming about $45 \%$ of the total raw material weight. This includes the head, gills, gut, red meat, fins and so on, which have the same nutritive value as fish. These byproducts have a low storage quality if not frozen or preserved. One of the methods available for byproduct utilization is fish meal production, which requires a huge capital investment. The use of relatively simpler technologies, like ensiling or fermentation of fish processing wastes, is more suitable and convenient for small industries and farmers (Faid, Zouiten \& Achkari-begdouri 1997). Effective utilization of fishery wastes has great potential as protein supplements in aquaculture feeds (Vidotti, Viegas \& Carneiro 2003). In 2001, around 30 million metric tonnes (MT) of waste fish product, including trimmings and other smaller bony fish, were used in aquafeeds (IFFO 2001). Normally, fish wastes are ensiled by biological fermentation with lactic acid bacteria or by chemical acidification using inorganic and/or organic acids (Tatterson 1982; Raa, Gildberg $\&$ Strom 1983). The experimental usage of fish silage as an alternative protein ingredient in aquafeeds has been widely reported (Raa \& Gildberg 1982; Hardy, Shearer \& Spinelli 1984; Arason 1994; Faid et al. 1997). Even though the technique for the production of silage is simple, its usage is limited in tropical aquaculture. This results from the failure to optimize methods of manufacture, the use of spoiled raw materials or poor storage conditions (Goddard \& Perret 2005). Co-drying of silage with wheat bran based on chemical and nutritional characteristics has been reported to improve storage conditions (Goddard \& Al-Yahyai 2001; Goddard, Mclean \& Wille 2003; Goddard \& Perret 2005). In a developing country 
such as India, the inclusion of co-fermented fish waste as an ingredient in aquafeeds for fish or crustaceans could reduce dependence on expensive, imported fish meal. It would also present an opportunity to utilize fishery waste, including bycatch and processing waste through aquaculture. In the present study, fish waste was processed by cofermentation using two different bacterial strains: Lactobacillus plantarum National Collection of Industrial Microorganisms (NCIM) 2912 and Bacillus licheniformis MTCC 6824. Two different experiments were performed and the changes in the nutritional profile were monitored for a period of 14 days.

\section{Materials and methods}

\section{Bacterial strains}

Lactobacillus plantarum NCIM 2912 was obtained from the NCIM, Pune, India and B. licheniformis MTCC 6824 was isolated from Mangalavanam, a local mangrove swamp. Lactobacillus plantarum was maintained in Lactobacilli Man, Rogosa and Sharpe (MRS) broth [composition: $\left(10.0 \mathrm{gL}^{-1}\right.$ protease peptone, $\mathrm{gL}^{-1}$ yeast extract, $10.0 \mathrm{~g} \mathrm{~L}^{-1}$ beef extract, $20.0 \mathrm{~g} \mathrm{~L}^{-1}$ dextrose, $1.0 \mathrm{~g} \mathrm{~L}^{-1}$ tween $80,2.0 \mathrm{~g} \mathrm{~L}^{-1}$ ammonium citrate, $5.0 \mathrm{~g} \mathrm{~L}^{-1}$ sodium acetate, $0.1 \mathrm{~g} \mathrm{~L}^{-1}$ magnesium sulphate, $0.05 \mathrm{gL}^{-1}$ manganese sulphate, and $2.0 \mathrm{~g} \mathrm{~L}^{-1}$ dipotassium phosphate), the medium was sterilized at $121{ }^{\circ} \mathrm{C}$ under $15 \mathrm{lb}$ for $15 \mathrm{~min}$ )] (De Man, Rogosa \& Sharpe 1972) with monthly sub culturing and B. licheniformis was maintained in wheat bran agar [WBA, composition: wheat bran extract $100 \mathrm{~mL}$ (100 g wheat bran in $1000 \mathrm{~mL}$ distilled water autoclaved for $1 \mathrm{~h}$ and filtered), $0.04 \mathrm{~g} \mathrm{~L}^{-1}$ $\left(\mathrm{NH}_{4}\right)_{2} \mathrm{SO}_{4}, 0.02 \mathrm{~g} \mathrm{~L}^{-1} \mathrm{MgSO}_{4} \cdot 7 \mathrm{H}_{2} \mathrm{O}, 1.0 \mathrm{~g} \mathrm{~L}^{-1}$ casein, $0.05 \mathrm{~g} \mathrm{~L}^{-1} \mathrm{KH}_{2} \mathrm{PO}_{4}, 0.04 \mathrm{~g} \mathrm{~L}^{-1} \mathrm{~K}_{2} \mathrm{HPO}_{4}, 2.0 \mathrm{~g} \mathrm{~L}^{-1}$ agar, 6.0-6.2 pH; the medium was sterilized at $121{ }^{\circ} \mathrm{C} 15 \mathrm{lb}$ for $15 \mathrm{~min}$ and $0.2 \mathrm{~mL} \mathrm{CaCl}_{2}$ from a sterile $2 \%$ stock solution was added].

\section{Co-fermentation of tuna waste}

The tuna waste was obtained from Integrated Fisheries Project, Cochin, India, which included red meat, gills, viscera, fins, etc. It was dried at $70^{\circ} \mathrm{C}$ and ground into a fine powder $(400 \mu \mathrm{m})$ for further use. The substrate used for fermentation was skipjack tuna (Katsuwonus pelamis) waste mixed with $25 \%$ wheat flour. For the two different experiments using L. plantarum and B. licheniformis, the basal medium for fermentation containing $50 \mathrm{~g}$ substrate with $50 \%$ moisture (adjusted with distilled water) was autoclaved at $121{ }^{\circ} \mathrm{C}$ for $15 \mathrm{~min}$ and inoculated with $5 \mathrm{~mL}$ of L. plantarum $\left(10^{8}-10^{9}\right.$ cells $\left.\mathrm{mL}^{-1}\right)$ and B. licheniformis $\left(10^{7}-10^{8}\right.$ cells $\left.\mathrm{mL}^{-1}\right)$ respectively. Triplicate samples in $500 \mathrm{~mL}$ conical flasks were incubated at $37^{\circ} \mathrm{C}$ for 14 days under a static condition. Sampling in triplicate was performed every $48 \mathrm{~h}$ for both the trials.

\section{Analyses of nutritional profile}

The products obtained after fermentation were dried to a constant moisture level in a hot air oven at 65$70{ }^{\circ} \mathrm{C}$ and proximate composition analyses were carried out (AOAC 1990). All analyses were performed in triplicate. The phosphorus and calcium contents in the fermented products were determined using the titrimetric method using the residue from ash, as described by AOAC (1990). Amino acid analysis of the fermented samples was performed after acid hydrolysis using $6 \mathrm{~N} \mathrm{HCl}$ by reverse-phase high-performance liquid chromatography (HPLC) after pre-column derivatization by phenyl isothiocyanate by a modified method adapted from Fierabracci et al. (1991). HPLC was performed using a Waters 1525 Binary HPLC pump and Waters 2487 Dual Absorbance Detector Data were processed and analysed using WATERS BREEZE software. The operating conditions were: column temperature $38^{\circ} \mathrm{C}$, column, pico-tag (waters, pico tag system); absorbance, $254 \mu \mathrm{m}$; and pump pressure, 1500-1700 psi. HPLC was performed using a Waters 1525 Binary HPLC pump and Waters 2487 Dual Absorbance Detector. Data were processed and analysed using WATERS BREEZE software. The tryptophan content in the samples was determined after alkaline hydrolysis by spectrophotometry (AOAC 1990).

\section{Statistical analyses}

Standardization of the fermentation process was statistically analysed using one-way analysis of variance. Significant differences among means $(P<0.05)$ (between days or between organisms as the case may be) were tested by Duncan's multiplerange tests. All statistical analyses were conducted using SPSs for Windows (Statistical Package for Social Sciences, Windows Version, Chicago, IL, USA) and MICROSOFT EXCEL. 


\section{Results and discussion}

The present study reports a practical method for co-fermentation of tuna waste from the canning industry using L. plantarum NCIM 2912 and B. licheniformis MTCC 6824. These resources, often discarded at sea, represent a potential global resource exceeding 30 million tonnes each year (New \& Csavas 1995). This is equivalent to the stock of fish currently targeted for fishmeal production (Barlow 2000). Fish processing wastes are found to be the only raw material that is regularly available but currently unutilized (Raghunath \& Gopakumar 2002). The preservation of fish waste generated from seafood processing offers a huge potential for effective utilization these wastes as an alternative protein source (Raa \& Gildberg 1982; Hardy et al. 1984; Arason 1994; Faid et al. 1997). Even though the dry fish waste contains $\geq 58 \%$ protein, it was presumed that more than protein-level enhancement, a kind of value addition is essential for it, which would convert the product that is more acceptable as a feed ingredient.

Dry waste was used in the present study because the product expected to obtain after fermentation was a low-moisture product, which is easy to handle, dry, transport and store, unlike the usual fish silage, which is bulky and difficult to handle, store and transport. Drying of fish waste was performed in hot air oven and the incubation was carried out in aircontrolled incubator, because its research requires sophistication. However, when large quantities are used, simpler techniques would definitely be requried, which is not difficult in this case because the sun drying at $>35^{\circ} \mathrm{C}$ and incubation at $37{ }^{\circ} \mathrm{C}$ are quite easy in many places because it is closer to the atmospheric temperature in tropical countries at least during certain months. For fermentation invol- ving bacteria at controlled moisture levels (40-70\%), the microbial action would be ideal if the substrate particle size is $400-600 \mu \mathrm{m}$ and that is why it was dried and ground.

The methodology followed for co-fermentation is viable because, a dried co-fermented product has a better shelf-life (because it is a dried product), is more balanced nutritionally (because no acid is added like for silage preparation) and is easy to transport to different places (it can be properly packed and sent). Fish silage is normally acidic in nature and semi liquid in condition, which is difficult to store on many occasions. Also, its use at the place of production is rarely possible, whereas the dry co-fermented product can reduce transport cost and optimize the storage and shelf-life, which is desirable for any feed ingredient. Studies have proven L. plantarum as one of the effective starter cultures (Bello, Gutierre, Ottati \& Martinez 1992), but the use of B. licheniformis for fermentation of fishery wastes has not been reported so far.

The proximate composition data of ingredient mix after fermentation using L. plantarum and B. licheniformis at different time intervals are given in Tables 1 and 2.With the progress of fermentation, an increase in the moisture content was observed for both Lactobacillus plantarum-fermented tuna (LPFT) and Bacillus licheniformis-fermented tuna (BLFT). For LPFT and BLFT, significant $(P<0.05)$ increase in the moisture content $(48.1 \%$ and $54 \%$ respectively) was observed on day 14 of fermentation. Fermentation of tuna waste resulted in a significant $(P<0.05)$ increase in the protein content of tuna waste between days 6 and 12. The increase observed in the crude protein content may be due to the bioconversion of soluble carbohydrates in the substrate (wheat flour) to bacterial protein. It has been demonstrated that

Table 1 Proximate composition of LPFT (as \% dry matter)

\begin{tabular}{llllrl}
\hline Day & Moisture & Crude protein & Crude fat & Crude ash & NFE \\
\hline 0 & $3.15 \pm 0.49^{\mathrm{a}}$ & $58.51 \pm 0.30^{\mathrm{a}}$ & $15.18 \pm 0.14$ & $5.30 \pm 0.22$ & $21.01 \pm 0.55^{\mathrm{a}}$ \\
2 & $2.81 \pm 0.55^{\mathrm{b}}$ & $59.59 \pm 0.37^{\mathrm{b}}$ & $15.50 \pm 0.18$ & $5.28 \pm 0.23$ & $19.63 \pm 0.26^{\mathrm{a}}$ \\
4 & $3.80 \pm 0.17^{\mathrm{c}}$ & $59.21 \pm 0.39^{\mathrm{c}}$ & $15.38 \pm 0.17$ & $5.09 \pm 0.44$ & $20.31 \pm 0.89^{\mathrm{b}}$ \\
6 & $4.00 \pm 0.17^{\mathrm{d}}$ & $60.62 \pm 0.86^{\mathrm{d}}$ & $15.47 \pm 0.08$ & $5.49 \pm 0.07$ & $18.42 \pm 0.97^{\mathrm{c}}$ \\
8 & $4.23 \pm 0.25^{\mathrm{e}}$ & $59.82 \pm 0.66^{\mathrm{e}}$ & $15.37 \pm 0.33$ & $5.46 \pm 0.07$ & $19.35 \pm 0.31^{\mathrm{d}}$ \\
10 & $4.70 \pm 0.10^{\mathrm{f}}$ & $60.31 \pm 0.75^{\mathrm{f}}$ & $15.70 \pm 0.11$ & $5.42 \pm 0.06$ & $18.56 \pm 0.90^{\mathrm{e}}$ \\
12 & $4.55 \pm 0.49^{\mathrm{g}}$ & $60.16 \pm 0.19^{\mathrm{g}}$ & $15.72 \pm 0.03$ & $5.50 \pm 0.05$ & $18.62 \pm 0.27^{\dagger}$ \\
14 & $6.07 \pm 1.63^{\mathrm{h}}$ & $61.83 \pm 1.12^{\mathrm{h}}$ & $15.79 \pm 0.48$ & $5.46 \pm 0.09$ \\
\hline
\end{tabular}

All values are average of triplicates \pm SE; means within the same columns with different superscript letters are significantly different $(P<0.05)$

LPFT, Lactobacillus plantarum-fermented tuna; NFE, Nitrogen free extract. 
Table 2 Proximate composition of BLFT (as \% dry matter)

\begin{tabular}{llllll}
\hline Day & Moisture & Crude protein & Crude fat & Crude ash & NFE \\
\hline 0 & $1.98 \pm 0.33^{\mathrm{a}}$ & $60.25 \pm 0.67$ & $14.89 \pm 0.30$ & $5.51 \pm 0.10$ & $19.34 \pm 0.81^{\mathrm{a}}$ \\
2 & $1.80 \pm 0.10^{\mathrm{b}}$ & $60.87 \pm 0.64$ & $14.97 \pm 0.90$ & $5.50 \pm 0.10$ & $18.66 \pm 1.34^{\mathrm{b}}$ \\
4 & $2.30 \pm 0.40^{\mathrm{c}}$ & $60.96 \pm 0.15$ & $15.83 \pm 0.66$ & $5.25 \pm 0.46$ & $17.96 \pm 0.48^{\mathrm{c}}$ \\
6 & $3.73 \pm 0.25^{\mathrm{d}}$ & $60.83 \pm 0.69$ & $15.50 \pm 0.07$ & $5.57 \pm 0.11$ & $18.10 \pm 0.64^{\mathrm{d}}$ \\
8 & $3.60 \pm 0.36^{\mathrm{e}}$ & $59.62 \pm 0.25$ & $15.66 \pm 0.85$ & $5.67 \pm 0.08$ & $19.05 \pm 1.03^{\mathrm{a}}$ \\
10 & $3.70 \pm 0.61^{\mathrm{f}}$ & $60.05 \pm 0.70$ & $15.42 \pm 0.92$ & $5.64 \pm 0.08$ & $18.89 \pm 1.63^{\mathrm{f}}$ \\
12 & $4.30 \pm 0.44^{\mathrm{g}}$ & $59.95 \pm 0.41$ & $15.98 \pm 0.22$ & $5.64 \pm 0.08$ & $18.43 \pm 0.40^{\mathrm{g}}$ \\
14 & $3.97 \pm 0.64^{\mathrm{h}}$ & $59.64 \pm 0.38$ & $15.73 \pm 0.25$ & $5.73 \pm 0.04$ & $18.90 \pm 0.61^{\mathrm{a}}$ \\
\hline
\end{tabular}

All values are average of triplicates \pm SE; means within the same columns with different superscript letters are significantly different $(P<0.05)$.

BLFT, Bacillus licheniformis-fermented tuna; NFE, Nitrogen free extract.

L. plantarum and B. licheniformis produce different enzymes and biomolecules, which are proteinaceous in nature during the course of fermentation (Hassan 2003; Nwanna 2003). The possibility of the production of non-protein nitrogen compounds-like ammonia, amines, amino acids and peptides due to autolysis during the process of fermentation also cannot be ignored (Haard, Kariel, Herzberg, Feltham \& Winter 1985). The crude fat content also showed a marginal increase in LPFT and BLFT (4\% and 7.3\% respectively), which can be attributed to the production of fatty acids by the bacterial strains. The increase in the crude fat content could be correlated with the increase in the protein content as reported by Arbogast and Henderson (1975), in that the polar lipid synthesis is associated with the protein synthesis because the enzymes required for the lipid synthesis are to be replaced by de novo protein synthesis. As such, fish wastes have a very low fibre content and it requires no further discussion, for the low crude fibre content in both LPFT and BLFT. The marginal increase in the ash content observed in both LPFT and BLFT may be attributed to the loss of dry matter during the process of fermentation (Puniya \& Singh 1995). The calcium and phosphorus contents also showed a slight increase up to day 10 in LPFT and BLFT and then a marginal reduction. The variations in the calcium and phosphorus levels LPFT and BLFT are given in Table 3.

The amino acid profiles of LPFT and BLFT are presented in Tables 4 and 5 respectively. For LPFT, a 24\% increase in the total amino acid content was observed on day 10. The best duration for fermentation based on the amino acid profile was between days 8 and 12 and a slight change was observed on day 8 , which requires further detailed analysis. The breakdown of proteins into free amino acids during silage produc-
Table 3 Calcium and Phosphorus content in LPFT and BLFT (expressed in \% dry matter) at different durations of fermentation

\begin{tabular}{|c|c|c|c|c|}
\hline \multirow{2}{*}{$\begin{array}{l}\text { Sample } \\
\text { (Day) }\end{array}$} & \multicolumn{2}{|l|}{ LPFT } & \multicolumn{2}{|l|}{ BLFT } \\
\hline & Calcium & Phosphorus & Calcium & Phosphorus \\
\hline 0 & 0.73 & 1.24 & 0.44 & 1.12 \\
\hline 2 & 0.86 & 1.24 & 0.50 & 1.20 \\
\hline 4 & 0.88 & 1.27 & 0.56 & 1.31 \\
\hline 6 & 0.95 & 1.33 & 0.60 & 1.33 \\
\hline 8 & 1.36 & 1.34 & 0.67 & 1.36 \\
\hline 10 & 1.63 & 1.33 & 0.73 & 1.47 \\
\hline 12 & 1.04 & 1.28 & 0.66 & 1.27 \\
\hline 14 & 0.93 & 1.09 & 0.46 & 1.27 \\
\hline
\end{tabular}

LPFT, Lactobacillus plantarum-fermented tuna; BLFT, Bacillus licheniformis-fermented tuna.

tion has already been reported (Tatterson \& Windsor 1974; Backhoff 1976). An increase in the levels of essential amino acids-like arginine, threonine, valine, isoleucine, leucine, lysine and tryptophan was observed in LPFT during the course of fermentation. A significant increase in the levels of aspartic acid, glutamic acid, glycine, alanine, proline and tyrosine was also observed in LPFT. A high correlation between glutathione dehydrogenase activity in lactic acid bacteria and their ability to catabolize amino acids in the presence of glutamine has been demonstrated in L. plantarum and Lactobacillus lactis (Tanous, Kieronczyk, Helinck, Chambellon \& Yvon 2002). The high negative values for the glutamine concentration correlated quite well with the increase in the glutamic acid concentration as a result of their possible interconversion, which may depend on the balance of ammonium, glutamate and glutamine concentrations (Chopin 1993). The increase in proteolytic activity shown for fish proteins might have caused maximal 
Table 4 Amino acid profile of LPFT at different durations of fermentation (expressed in $\mathrm{g} 100 \mathrm{~g}^{-1}$ sample)

\begin{tabular}{|c|c|c|c|c|c|c|c|c|}
\hline Amino acids & Day 0 & Day 2 & Day 4 & Day 6 & Day 8 & Day 10 & Day 12 & Day 14 \\
\hline Aspartic acid & $4.00 \pm 0.15$ & $4.22 \pm 0.04$ & $4.02 \pm 0.01$ & $4.23 \pm 0.04$ & $4.82 \pm 0.00$ & $4.84 \pm 0.89$ & $4.78 \pm 0.04$ & $4.37 \pm 0.15$ \\
\hline Glutamic acid & $6.67 \pm 2.04$ & $8.54 \pm 0.00$ & $8.15 \pm 0.05$ & $8.40 \pm 0.01$ & $9.47 \pm 0.02$ & $.91 \pm 0.26$ & $8.23 \pm 0.10$ & $8.63 \pm 0.35$ \\
\hline Serine & $3.18 \pm 1.77$ & $2.07 \pm 0.01$ & $2.14 \pm 0.01$ & $2.17 \pm 0.00$ & $2.35 \pm 0.01$ & $2.62 \pm 0.06$ & $2.59 \pm 0.05$ & $2.11 \pm 0.07$ \\
\hline Glycine & $1.73 \pm 1.07$ & $2.54 \pm 0.01$ & $3.18 \pm 0.15$ & $3.23 \pm 0.05$ & $3.18 \pm 0.01$ & $3.35 \pm 0.14$ & $3.61 \pm 0.01$ & $3.18 \pm 0.10$ \\
\hline Histidine & $3.98 \pm 2.51$ & $2.62 \pm 0.08$ & $2.87 \pm 0.34$ & $2.69 \pm 0.03$ & $2.77 \pm 0.02$ & $2.95 \pm 0.12$ & $2.89 \pm 0.23$ & $2.91 \pm 0.09$ \\
\hline Arginine & $3.37 \pm 0.37$ & $3.97 \pm 0.16$ & $4.02 \pm 0.05$ & $4.33 \pm 0.03$ & $4.43 \pm 0.23$ & $4.73 \pm 0.40$ & $3.91 \pm 0.13$ & $4.40 \pm 0.10$ \\
\hline Threonine & $2.30 \pm 0.32$ & $2.43 \pm 0.10$ & $2.36 \pm 0.04$ & $2.30 \pm 0.01$ & $2.60 \pm 0.16$ & $2.75 \pm 0.12$ & $3.20 \pm 0.06$ & $2.39 \pm 0.11$ \\
\hline Alanine & $2.03 \pm 1.04$ & $2.80 \pm 0.03$ & $3.03 \pm 0.05$ & $3.11 \pm 0.02$ & $3.33 \pm 0.02$ & $3.44 \pm 0.30$ & $3.29 \pm 0.07$ & $3.14 \pm 0.12$ \\
\hline Proline & $2.42 \pm 0.47$ & $2.24 \pm 0.02$ & $2.81 \pm 0.02$ & $2.88 \pm 0.03$ & $2.75 \pm 0.01$ & $3.49 \pm 0.24$ & $4.62 \pm 0.00$ & $2.81 \pm 0.08$ \\
\hline Tyrosine & $2.33 \pm 1.43$ & $1.56 \pm 0.01$ & $1.61 \pm 0.01$ & $1.73 \pm 0.03$ & $1.78 \pm 0.01$ & $2.13 \pm 0.58$ & $1.91 \pm 0.04$ & $1.81 \pm 0.06$ \\
\hline Valine & $1.77 \pm 0.86$ & $2.68 \pm 0.06$ & $2.61 \pm 0.02$ & $2.69 \pm 0.03$ & $3.02 \pm 0.02$ & $3.28 \pm 0.20$ & $3.18 \pm 0.12$ & $2.83 \pm 0.10$ \\
\hline Methionine & $2.14 \pm 1.34$ & $1.58 \pm 0.06$ & $1.48 \pm 0.00$ & $1.66 \pm 0.05$ & $1.75 \pm 0.00$ & $2.05 \pm 0.19$ & $2.09 \pm 0.02$ & $1.68 \pm 0.05$ \\
\hline Cystine & $1.01 \pm 1.29$ & $0.14 \pm 0.10$ & $0.22 \pm 0.01$ & $0.31 \pm 0.02$ & $0.32 \pm 0.00$ & $0.27 \pm 0.06$ & $0.40 \pm 0.39$ & $0.34 \pm 0.01$ \\
\hline Isoleucine & $1.14 \pm 1.19$ & $2.09 \pm 0.04$ & $2.24 \pm 0.02$ & $2.20 \pm 0.03$ & $2.47 \pm 0.02$ & $2.41 \pm 0.21$ & $2.16 \pm 0.00$ & $2.37 \pm 0.04$ \\
\hline Leucine & $2.68 \pm 0.83$ & $3.51 \pm 0.01$ & $3.69 \pm 0.04$ & $3.62 \pm 0.01$ & $4.11 \pm 0.04$ & $3.92 \pm 0.25$ & $3.48 \pm 0.02$ & $3.91 \pm 0.16$ \\
\hline Phenylalanine & $2.68 \pm 1.40$ & $1.81 \pm 0.04$ & $2.10 \pm 0.01$ & $2.06 \pm 0.03$ & $2.17 \pm 0.01$ & $2.19 \pm 0.18$ & $2.17 \pm 0.04$ & $2.19 \pm 0.07$ \\
\hline Lysine & $2.06 \pm 1.51$ & $3.45 \pm 0.02$ & $3.13 \pm 0.00$ & $3.20 \pm 0.07$ & $3.78 \pm 0.00$ & $2.98 \pm 0.97$ & $3.91 \pm 0.18$ & $3.59 \pm 0.13$ \\
\hline Tryptophan & $0.98 \pm 0.00$ & $0.11 \pm 0.00$ & $0.94 \pm 0.00$ & $0.98 \pm 0.00$ & $1.17 \pm 0.00$ & $1.28 \pm 0.00$ & $1.12 \pm 0.00$ & $0.92 \pm 0.00$ \\
\hline
\end{tabular}

All values are average of triplicates $\pm \mathrm{SE}$.

LPFT, Lactobacillus plantarum-fermented tuna.

Table 5 Amino acid profile of BLFT fermented tuna (expressed in $\mathrm{g} 100 \mathrm{~g}^{-1}$ sample)

\begin{tabular}{lllllllll}
\hline Amino acids & Day 0 & Day 2 & Day 4 & Day 6 & Day 8 & Day 10 & Day 12 & Day 14 \\
\hline Aspartic acid & $3.08 \pm 0.03$ & $3.93 \pm 0.14$ & $3.69 \pm 0.08$ & $3.90 \pm 0.01$ & $4.61 \pm 0.28$ & $4.65 \pm 0.14$ & $3.06 \pm 0.02$ & $4.48 \pm 0.04$ \\
Glutamic acid & $6.35 \pm 0.02$ & $7.99 \pm 0.34$ & $7.58 \pm 0.17$ & $8.07 \pm 0.01$ & $9.20 \pm 0.54$ & $9.15 \pm 0.25$ & $8.05 \pm 0.04$ & $8.95 \pm 0.04$ \\
Serine & $1.72 \pm 0.01$ & $1.92 \pm 0.18$ & $1.87 \pm 0.08$ & $1.89 \pm 0.01$ & $2.05 \pm 0.13$ & $2.07 \pm 0.01$ & $2.43 \pm 0.01$ & $1.99 \pm 0.00$ \\
Glycine & $2.50 \pm 0.01$ & $2.84 \pm 0.04$ & $2.86 \pm 0.07$ & $3.17 \pm 0.01$ & $3.05 \pm 0.21$ & $3.28 \pm 0.12$ & $3.31 \pm 0.01$ & $2.96 \pm 0.00$ \\
Histidine & $2.31 \pm 0.03$ & $2.90 \pm 0.27$ & $3.09 \pm 0.19$ & $2.58 \pm 0.06$ & $2.92 \pm 0.03$ & $2.98 \pm 0.07$ & $2.78 \pm 0.24$ & $2.80 \pm 0.00$ \\
Arginine & $3.37 \pm 0.05$ & $3.99 \pm 0.29$ & $3.75 \pm 0.07$ & $4.14 \pm 0.10$ & $3.89 \pm 1.03$ & $4.37 \pm 0.13$ & $5.50 \pm 0.12$ & $4.27 \pm 0.10$ \\
Threonine & $1.97 \pm 0.01$ & $2.28 \pm 0.17$ & $2.17 \pm 0.18$ & $2.28 \pm 0.04$ & $2.42 \pm 0.03$ & $2.61 \pm 0.04$ & $3.04 \pm 0.07$ & $2.43 \pm 0.04$ \\
Alanine & $2.31 \pm 0.03$ & $2.83 \pm 0.13$ & $2.83 \pm 0.05$ & $3.09 \pm 0.04$ & $3.24 \pm 0.05$ & $3.31 \pm 0.12$ & $3.30 \pm 0.02$ & $3.09 \pm 0.00$ \\
Proline & $2.26 \pm 0.04$ & $2.60 \pm 0.10$ & $2.79 \pm 0.18$ & $3.13 \pm 0.05$ & $2.71 \pm 0.06$ & $2.90 \pm 0.01$ & $4.09 \pm 0.10$ & $2.58 \pm 0.03$ \\
Tyrosine & $1.71 \pm 0.04$ & $1.62 \pm 0.03$ & $1.64 \pm 0.20$ & $1.70 \pm 0.02$ & $2.10 \pm 0.56$ & $1.79 \pm 0.05$ & $1.77 \pm 0.01$ & $1.71 \pm 0.01$ \\
Valine & $2.24 \pm 0.04$ & $2.56 \pm 0.05$ & $2.53 \pm 0.20$ & $2.61 \pm 0.03$ & $3.44 \pm 0.65$ & $2.95 \pm 0.01$ & $3.41 \pm 0.13$ & $2.87 \pm 0.00$ \\
Methionine & $1.35 \pm 0.04$ & $1.51 \pm 0.05$ & $1.48 \pm 0.22$ & $1.51 \pm 0.03$ & $1.69 \pm 0.08$ & $1.73 \pm 0.07$ & $2.04 \pm 0.07$ & $1.61 \pm 0.00$ \\
Cystine & $0.27 \pm 0.06$ & $0.14 \pm 0.01$ & $0.30 \pm 0.13$ & $0.14 \pm 0.03$ & $0.35 \pm 0.12$ & $0.33 \pm 0.09$ & $0.59 \pm 0.00$ & $0.33 \pm 0.02$ \\
Isoleucine & $1.84 \pm 0.07$ & $2.16 \pm 0.05$ & $2.10 \pm 0.07$ & $2.22 \pm 0.04$ & $3.00 \pm 0.72$ & $2.47 \pm 0.03$ & $2.19 \pm 0.01$ & $2.32 \pm 0.03$ \\
Leucine & $3.00 \pm 0.03$ & $3.53 \pm 0.02$ & $3.46 \pm 0.10$ & $3.64 \pm 0.05$ & $4.20 \pm 0.10$ & $4.09 \pm 0.14$ & $3.57 \pm 0.05$ & $3.91 \pm 0.02$ \\
Phenylalanine & $1.76 \pm 0.04$ & $2.01 \pm 0.12$ & $2.08 \pm 0.17$ & $2.15 \pm 0.00$ & $2.16 \pm 0.02$ & $2.21 \pm 0.04$ & $2.11 \pm 0.02$ & $2.06 \pm 0.00$ \\
Lysine & $2.85 \pm 0.04$ & $3.28 \pm 0.28$ & $2.90 \pm 0.11$ & $2.93 \pm 0.00$ & $4.00 \pm 0.15$ & $3.80 \pm 0.12$ & $4.10 \pm 0.15$ & $3.65 \pm 0.00$ \\
Tryptophan & $1.36 \pm 0.00$ & $1.44 \pm 0.00$ & $1.24 \pm 0.00$ & $1.16 \pm 0.00$ & $1.30 \pm 0.00$ & $1.18 \pm 0.00$ & $0.87 \pm 0.00$ & $1.61 \pm 0.00$ \\
\hline
\end{tabular}

All values are average of triplicates $\pm \mathrm{SE}$.

BLFT, Bacillus licheniformis-fermented tuna.

increases in lysine, and arginine levels, according to the specificity of L. plantarum for the substrate. A similar observation was made by Silvina, Sauz, Vignolo, Aristoy, Oliver and Toldra (1999) in terms of an increase in lysine and arginine levels after fermentation. Yeast and lactic acid bacteria convert free amino acids by Erlich's mechanism to flavour compounds such as alcohols. These alcohols have one carbon less than the corresponding amino acids. For example, valine, leucine and phenylalanine are converted, respectively, to isobutanol, 3-methylbutanol and 2-phenylethanol (Molard 1994). Histidine, phenylalanine and methionine have been reduced in LPFT compared with the unfermented mix. A reduction in serine and cysteine was also observed in the present study. Various amino acids, vitamins 
and minerals are essential for the growth and metabolism of lactic acid bacteria (Kandler \& Weiss 1986). Predominant utilization of serine by homo-fermentative lactobacilli like L. plantarum for their growth was reported by Liu, Holland and Crow (2003). Another reason for the decrease in the amino acid content may be due to the chemical reactions between $\alpha$-amino acids and aldehyde groups present as a result of a Maillard reaction (Johnson, Brown, Eason \& Sumner 1985; Fagbenro \& Jauncey 1995) or due to the deamination of certain amino acids (Dapkevicius, Robert Nout, Rombouts, Houben \& Wymenga 2000).

For BLFT, except tryptophan (it increased on day 2 and then showed a reduction), all other amino acids increased during the course of fermentation (Table 5). When present in proteins, tryptophan is stable at a low pH, but is labile when free (Jackson, Kerr \& Cowey 1984). The loss of tryptophan was reported as one of the most serious effects of long-term storage of silage (Jensen \& Schmidtsdorff 1977; Kompiang, Yushadi \& Creswell 1980). An increase in the levels of histidine, threonine and serine for biological and acid silage production has been reported by Vidotti et al. (2003). Higher levels of histidine were reported in both fresh sprat and resulting silages by Jackson et al. (1984). Leucine is a stimulatory precursor, which is also an inducer for bacitracin synthetase in the production of bacitracin (an antibiotic) by B. licheniformis (Haavik \& Froyshov 1982). It has been demonstrated that during fermentation, certain amino acids are produced, with the improved availability of vitamins (Nout \& Motarjemi 1997). The increase in the amino acid content in the BLFT may be due to the hydrolysis of protein to amino acid fractions as well as synthesis by the bacteria (Espe, Raa \& Njaa 1989; Hassan 2003; Lee, Kim \& Kim 2004).

A reduction in tryptophan is common in acid medium, especially in the case of acid ensilage process, but in the present study, a neutral $\mathrm{pH}$ was provided for fermentation and no acid was added. It is the bacteria that acted upon the substrate for fermentation, and a reduction in tryptophan in BLFT and not in LPFT was observed. In the BLFT, B. licheniformes would have reduced the substrate $\mathrm{pH}$ during fermentation, thereby resulting in tryptophan reduction and B. plantarum would have maintained the $\mathrm{pH}$ in the substrate during fermentation without affecting the level of tryptophan.

In the present study, the ratio of non-essential amino acids to essential amino acids was observed to be
2:1 throughout the fermentation process. The maximum values for amino acids were obtained between days 8 and 12, indicating it to be the peak phase of proteinaceous microbial metabolite production.

The results of the present study suggest the use of co-fermented tuna waste as a novel ingredient, which has the potential to be used as an alternative to fishmeal in aquafeeds.

\section{Acknowledgments}

The authors acknowledge Director, Central Marine Fisheries Research Institute (CMFRI), Kochi, Kerala, India, for the facilities provided. The financial support provided to the first author by Central Institute of Fisheries Education (CIFE), Mumbai, India, is gratefully acknowledged. The authors thank Mrs G. Shylaja, Technical Officer, CMFRI, for amino acid analysis.

\section{References}

AOAC. (1990) Official Methods of Analysis of the Association of Analytical Chemists, 15th edn. Association of Analytical Chemists, Arlington, TX, USA, 1298pp.

Arason S. (1994) Production of fish silage. In: Fisheries Processing (ed. by A.M. Martin), pp. 245-271. Chapman and Hall, London, UK.

Arbogast L.Y. \& Henderson T.O. (1975) Effect of inhibition of protein synthesis on lipid metabolism in Lactobacillus plantarum. Journal of Bacteriology 123, 962-971.

Backhoff H.P. (1976) Some chemical changes in fish silage. Journal of Food Technology 11, 353-363.

Barlow S. (2000) Fish meal and fish oil: sustainable feed ingredients for aquafeeds. Global Aquaculture Advocate $\mathbf{3}$, $85-88$.

Bello R.A., Gutierre M., Ottati M. \& Martinez A. (1992) Study on the processing of fish silage microbilogically in Venezuela. Paper presented at the 2 nd experts consultation on fisheries products technology in Latin America, Montevideo. 11-15 December, 1989, FAO, Rome, Italy, No. 441 (Suppl.), pp. 1-17.

Chopin A. (1993) Organization and regulation of genes for amino acid biosynthesis in lactic acid bacteria. FEMS Microbiology Review 12, 21-37.

Dapkevicius M.L.N.E., Robert Nout M.J., Rombouts F.M., Houben J.H. \& Wymenga W. (2000) Biogenic amine formation and degradation by potential fish silage starter microorganisms. International Journal of Food Microbiology 57, 107-114.

De Man J., Rogosa M. \& Sharpe M.E. (1972) A medium for the cultivation of lactobacilli. Journal of Applied Bacteriology 23, 130-135. 
Espe M., Raa J. \& Njaa L.R. (1989) Nutritional value of stored fish silage as a protein source for young rats. Journal of Science Food and Agriculture 49, 259-270.

Fagbenro O. \& Jauncey K. (1995) Water stability, nutrient leaching and nutritional properties of moist fermented fish silage diets. Aquaculture Engineering 14, 143-153.

Faid M., Zouiten A. \& Achkari-Begdouri A. (1997) Biotransformation of fish waste into a stable feed ingredient. Food Chemistry 60, 13-18.

Fierabracci V., Masiello P., Novelli M. \& Bergamini E. (1991) Application of amino acid analysis by high-performance liquid chromatography with phenyl isothiocyanate derivitization to the rapid determination of free amino acids in biological samples. Journal of Chromatography $\mathbf{5 7 0}$, 285-291.

Goddard J.S. \& Al-Yahyai D.S.S. (2001) Chemical and nutritional characteristics of dried sardine silage. Journal of Aquatic Food Product Technology 10,39-50.

Goddard J.S. \& Perret J.S.M. (2005) Co-drying fish silage for use in aqua feeds. Animal Feed Science Technology 118 , 337-342.

Goddard J.S., McLean E. \& Wille K. (2003) Co-dried sardine silage as an ingredient in tilapia, Oreochromis aureus, diets. Journal of Aquaculture in the Tropics 18, 257-264.

Haard N.F., Kariel N., Herzberg G.W., Feltham L.A. \& Winter K. (1985) Stabilisation of protein and oil in fish silage for use as a ruminant feed supplement. Journal of Science Food and Agriculture 36, 229-241.

Haavik H.I. \& Froyshov O. (1982) On the role of L-luecine in the control of bacitracin formation by Bacillus licheniformis. In: Peptide Antibiotics: Biosynthesis and Functions. (ed. by H. Kleinkauf \& H. van Dohren), pp. 155-159. Walter de Gruyter and Co, Berlin, Germany.

Hardy R.W., Shearer K.D. \& Spinelli J. (1984) The nutritional properties of co-dried fish silage in rainbow trout (Salmo gairdneri) dry diets. Aquaculture 38, 35-44.

Hassan B. (2003) Fermentation of Fish Silage using Lactobacillus pentosus. Journal Nature Indonesia 6, 11-15.

IFFO. (2001) Sustainability of fish meal and oil supply. http:// www.iffo.org.uk/tech/sterlling.htm.16.4.2004.

Jackson A.S., Kerr A.K.R. \& Cowey C.B. (1984) Fish silage as a dietary ingredient for salmon. I. Nutritional and storage characteristics. Aquaculture 38, 211-220.

Jensen J. \& Schmidtsdorff W. (1977) Fish silage, low fat and soluble fish protein products. In: Symnposium on the Production of Fish Meal, Szezecin, Poland. (ed. by F. Martin), pp. 23-36. International Association of Fish Meal Manufacturers, Hertfordshrine, UK.

Johnson R.J., Brown N., Eason P. \& Sumner J. (1985) The nutritional quality of two types of fish silage for broiler chickens. Journal of Science Food and Agriculture 36, 9-12.

Kandler O. \& Weiss N. (1986) Genus Lactobacillus Beijerinck 1901, 212 ${ }^{\text {AL }}$. In: Bergey's Manual of Systematic Bacteriology, Vol. 2 (ed. by P.H.A. Sneath, N.S. Mair, M.E. Sharpe \& J.G. Holt), pp.1209-1234. Williams and Wilkins, Baltimore.
Kompiang I.,Yushadi P. \& Creswell D.C. (1980) Microbial fish silage: chemical composition, fermentation characteristics and nutritional value. FAO Fish. Rep. No. 230, 38-43.

Lee S.M., Kim K.D. \& Kim T.J. (2004) Utilization of fermented skipjack tuna viscera as a dietary protein source replacing fish meal or soybean meal for juvenile abalone Haliotis discus hannai. Journal of Shellfish Research 15, 1059-1064.

Liu S.Q., Holland R. \& Crow V.L. (2003) The potential of dairy lactic acid bacteria to metabolise amino acids via non-transaminating reactions and endogenous transamination. International Journal of Food Microbiology 86, 257-269.

Molard R. (1994) Bread flour. French Bread Making 4, 453 477.

New M. \& Csavas I. (1995) Will there be enough fish meal for fish meals? Aquaculture Europe 19, 6-13.

Nout M.J.R. \& Motarjemi Y. (1997) Assessment of fermentation as a household technology for improving food safety: a joint FAO/VVHO workshop. Food Control 8, 221-226.

Nwanna L.C. (2003) Nutritional value and digestibility of fermented shrimp head waste meal by African catfish Clarias gariepinus. PakistanJournal of Nutrition 2, 339-345. Puniya A.K. \& Singh K. (1995) Biochemical changes during the solid substrate fermentation of wheat straw. Indian Journal of Microbiology 35, 211-215.

Raa J. \& Gildberg A. (1982) Fish silage: a review. CRC Critical Reviews in Food Science and Nutrition 16, 383-419.

Raa J., Gildberg A. \& Strom T. (1983) Silage production - theory and practice. In: Upgrading Waste for Feeds and Food (ed. by D.A. Ledward, A.J. Taylor \& R.A. Lawrie), pp. 117-132. Butterworths, London, UK.

Raghunath M.R. \& Gopakumar K. (2002) Trends in production and utilization of fish silage. Journal of Food Science Technology 39, 103-110.

Silvina F., SauzY.,Vignolo G., Aristoy M.C., Oliver G. \& Toldra F. (1999) Characterisation of muscle sarcoplasmic and myofibrillar protein hydrolysis caused by Lactobacillus plantarum. Applied Environmental Microbiology 65, 35403546.

Tanous C., Kieronczyk A., Helinck S., Chambellon E. \& Yvon M. (2002) Glutamate dehydrogenase activity: a major criterion for the selection of flavour-producing lactic acid bacteria strains. Antonie Van Leeuwenhoek International Journal of General Molecular Microbiology 82, 271-278.

Tatterson I.N. (1982) Fish silage- preparation, properties and uses. Animal Feed Science Technology 7, 153-159.

Tatterson I.N. \& Windsor M.L. (1974) Fish silage. Torry Advisory Note, No. 64. (Torry Advisory Notes are available on the one Fish web site, http://www.onefish.org).

Vidotti R.M., Viegas E.M.M. \& Carneiro D.J. (2003) Amino acid composition of processed fish silage using different raw materials. Animal Feed Science Technology 105, 199-204. 